\title{
Extracellular Microvesicles (MV's) Isolated from 5-Azacytidine-and-Resveratrol-Treated Cells Improve Viability and Ameliorate Endoplasmic Reticulum Stress in Metabolic Syndrome Derived Mesenchymal Stem Cells
}

\author{
C Weiss $^{1} \cdot$ K Kornicka-Grabowska ${ }^{2,3} \cdot$ M Mularczyk $^{2,3} \cdot$ N Siwinska $^{4} \cdot$ K Marycz $^{2,3,5}$ (D)
}

Published online: 3 September 2020

(C) The Author(s) 2020

\begin{abstract}
Extracellular vesicles (EVs), a spherical membrane fragments including exosomes, are released from several cell types, including mesenchymal stromal cells (MSCs), constitutively or under stimulation. As MVs cargo include DNA, RNA, miRNA, lipids and proteins their have gain special attention in the field of regenerative medicine. Depending on the type of transferred molecules, MVs may exert wide range of biological effects in recipient cells including pro-inflammatory and anti-apoptotic action. In presented paper, we isolated MVs form adipose derived mesenchymal stem cells (ASC) which underwent stimulation with 5azacytydine and resveratrol (AZA/RES) in order to improve their therapeutic potential. Then, isolated MVs were applied to ASC with impaired cytophysiological properties, isolated from equine metabolic syndrome diagnosed animals. Using RT-PCR, immunofluorescence, ELISA, confocal microscopy and western blot, we have evaluated the effects of MVs on recipient cells. We have found, that MVs derived from AZA/RES treated ASC ameliorates apoptosis, senescence and endoplasmic reticulum (ER) stress in deteriorated cells, restoring their proper functions. The work indicates, that cells treated with AZA/RES through their paracrine action can rejuvenate recipient cells. However, further research needs to be performed in order to fully understand the molecular mechanisms of these bioactive factors action.
\end{abstract}

Keywords Stem cells $\cdot$ Extracellular vesicles $\cdot$ Rejuvenation

\section{Introduction}

Electronic supplementary material The online version of this article (https://doi.org/10.1007/s12015-020-10035-4) contains supplementary material, which is available to authorized users.

K Marycz

krzysztofmarycz@interia.pl

1 PferdePraxis Dr. Med. Vet. Daniel Weiss, Postmatte 14, CH-8807 Freienbach, Switzerland

2 Department of Experimental Biology, Wroclaw University of Environmental and Life Sciences, Norwida 27B street, A7 building, 50-375 Wroclaw, Poland

3 International Institute of Translational Medicine, Malin, Jesionowa 11, 55-114 Wisznia Mała, Poland

4 Department of Internal Medicine and Clinic of Diseases of Horses, Dogs and Cats, Faculty of Veterinary Medicine, Wroclaw University of Environmental and Life Sciences, Pl. Grunwaldzki 47, 50-366 Wroclaw, Poland

5 Faculty of Veterinary Medicine, Equine Clinic-Equine Surgery, Justus-Liebig-University, 35392 Giessen, Germany
Regenerative medicine therapies based on the application of stem cells hold grate promise not only for the treatment of musculoskeletal system disorders but also in the course of endocrine diseases [1,2]. Sedentary life style, obesity, insulin resistance or insulin dysregulations are common features associated with type II diabetes (T2D) or syndrome X (MetS) development. Recently, due to increased prevalence, MetS have become a subject of extensive research in human as well as in veterinary endocrinology. Equine metabolic syndrome (EMS) is characterized by insulin resistance, past or chronic laminitis and adiposity in specific location such as around eyes or on the base of the tail [3]. Nowadays, EMS is frequently diagnosed disease affecting horses population worldwide and if not treated properly, may lead to the development of laminitis - a life-threatening disease [3]. Interestingly, laminitis can be partially compared to cardiovascular complications occurring in humans during metabolic disorders. Furthermore, more and more research have proven that horse model have been applied for the study of certain diseases in humans thus 
possess great potential for translational medicine [4-6]. Therefore, an equine model of metabolic syndrome is proposed for translational research in humans regarding metabolic disorders and their consequences.

Recently, more and more attention has been paid toward application of stem cells for treatment of endocrine disorders including T2D or EMS. Due to their unique properties, abundance and ease of isolation, mesenchymal progenitor cells (MSC) from bone marrow (BMSC) and adipose tissue (ASC) are under intensive investigation in multiple clinical trials all over the world [7-11]. MSCs are characterized by multilineage differentiation potential, anti-inflammatory as well as immunomodulatory properties which are responsible for therapeutic potential of MSC in the course of different disorders including T2D and EMS [1, 12-16]. As recently showed, the plausible mechanism of MSC action can be at least partially explain by their paracrine activity. MSCs secrete extracellular microvesicles (MVs)- a spherical membrane fragments including exosomes which carry different type of biological cargo, including proteins, peptides, mRNA, lipids and miRNA [17]. For that reason, MVs similar to the cells of origin, are characterised by great therapeutic potential and since now have been successfully applied in the treatment of multiple disorders including liver, kidney, lung myocardial injuries or EMS [18-20]. Numerous studies showed, that MV's are rich in growth factors which induce and mediate regeneration process e.g. vascular endothelial growth factor (VEGF), insulin-like growth factor 1 (IGF-1), basic fibroblast growth factors (bFGF), interleukin 6 (IL-6), chemokine (C-C motif) ligand 2 (CCL-2) and hepatocyte growth factor (HGF) [17, 21-23]. It was shown, that MVs are able to modulate immune response, diminish inflammation and modulate regenerative properties of recipient cells [17, 23]. However, the pro-regenerative properties of MV's strongly depends on the physiological condition of MSCs from which they originate. In our previous research, we demonstrated, that EMS derived ASC suffer from reduced proliferative activity, enhanced apoptosis and abundant oxidative stress factors accumulation which leads to their senescence [24, 25]. Moreover, it was showed, that insulin resistance impairs multilineage differentiation potential of EMS derived ASCs due to amelioration of mitochondrial biogenesis and dynamics [26]. As a result of insulin resistance, impairment of autophagy and mitophagy occurs, leading to deterioration of ASCs proregenerative potential. In consequence application of autologous ASC during EMS is limited and may not exert expected therapeutic outcome. However, our previous studies have shown that a combination of 5-azacytydine (AZA) and resveratrol (RES) is able to reverse aged phenotype of these cells. It was shown, that AZA/RES increase proliferative potential, reduces apoptosis and improve multilineage differentiation potential of ASC derived from EMS individuals [27-29]. Rejuvenated ASCs has more abundantly produced MVs rich in immunomodulatory factors which serves as anti-oxidative defense against free radicals produce under EMS condition and modulate activity of immune cells [29]. Therefore, in presented study we decided to further investigate the biological activity of MVs isolated from AZA/RES treated cells. It was investigated, whether similar to AZA/RES, MVs are originating from rejuvenated cells can modulate apoptosis, oxidative stress and mitophagy in recipient progenitor cells isolated from EMS horses. As it was demonstrated, that the combination of AZA/RES abolish negative consequences of free radicals accumulation and rejuvenate impaired cells, we hypothesized that MVs originating from these cells are also able to improve cytophysiological properties of recipient cells.

\section{Results}

\section{Evaluation of Cellular Viability}

Scheme of MVs isolation is shown at Fig. 1a. In order to select most beneficial concentration, Alamar blue assay was performed (Fig. 1b). Cells were cultured for $24 \mathrm{~h}$ with five different concentration of MVs and their viability was established after 24, 48, 72 and $96 \mathrm{~h}$ of culture. MVs concentration equalled $25 \mu \mathrm{g} / \mathrm{ml}$ was shown to significantly enhance cellular viability. For that reason, it was selected and applied in further experiments. Obtained results indicated on decreased proliferation in ASC EMS however it was enhanced after treatment of cells with MVs AZA/RES (Fig. 1c). Treatment of cells with MVs AZA/RES reduced amount of NO (Fig. 1d) and ROS (Fig. 1e) while increased activity of SOD (Fig. 1f).

\section{Assessment of Apoptosis}

Live, dead cells and those accumulating $\beta$-galactosidase was visualized using specific stainings (Fig. 2a). Apoptosis was also investigated using TUNEL staining which indicated on increased number of dead cells in ASC EMS however that phenomenon was reversed after treatment of cells with MVs AZA/RES (Fig. 1a). Propidium Iodide staining (Fig. 2b) and $\beta$-galactosidase (Fig. 2c) was further quantified and presented as a percentage of positive cells. Obtained results shown that treatment of cells with MVs AZA/RES reduce number of dead and senescent cells. Expression of p53 was significantly

Fig. 1 Evaluation of viability and oxidative stress factors in cells. Scheme of MVs isolation (a). The influence of different MVs concentration on cells (b). Levels of BrdU incorporation (c), NO (d), ROS (e) and SOD (f) in ASC HE, ASC EMS and ASC EMS treated with $25 \mu \mathrm{g} / \mathrm{ml} \mathrm{MVs} \mathrm{AZA/}$ RES. Results expressed as mean $\pm \mathrm{SD} . * P<0.05 ; * * P<0.01$; $* * * P<0.001$. b and $\mathbf{c}$ are reproduced from Kornicka-Garbowska et al. under Creative Commons licence (https://www.ncbi.nlm.nih.gov/pmc/ articles/PMC6921487/) 
a

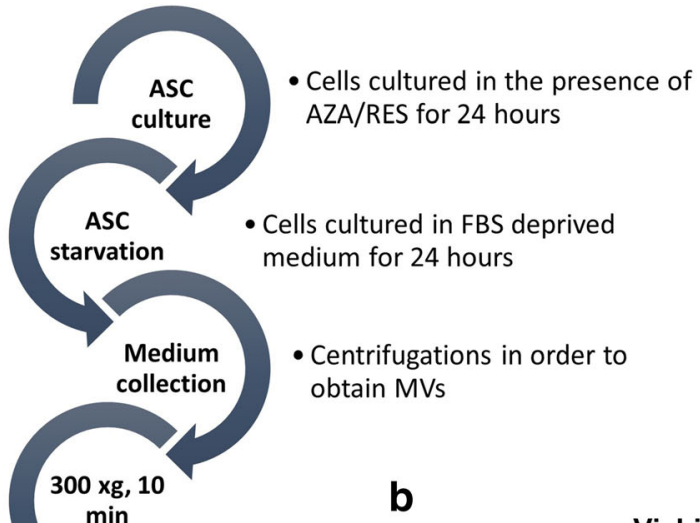

min

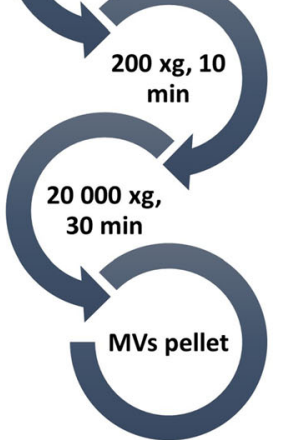

C

BrdU

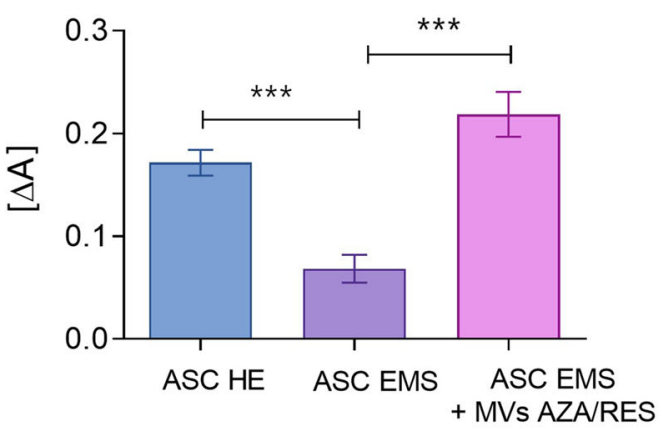

d

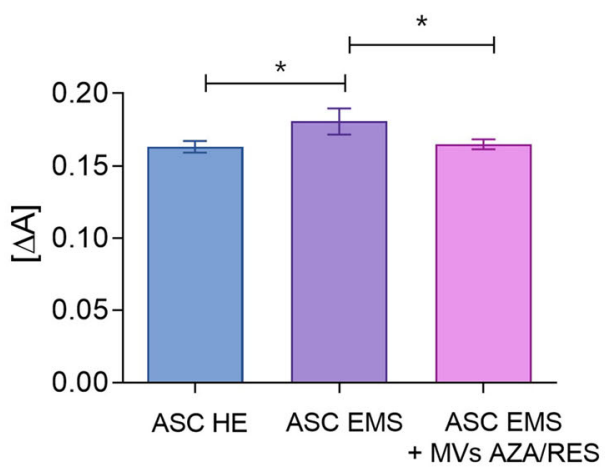

d

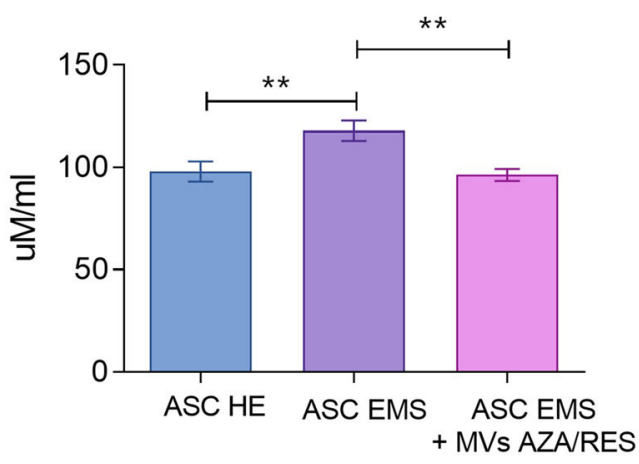

e

SOD

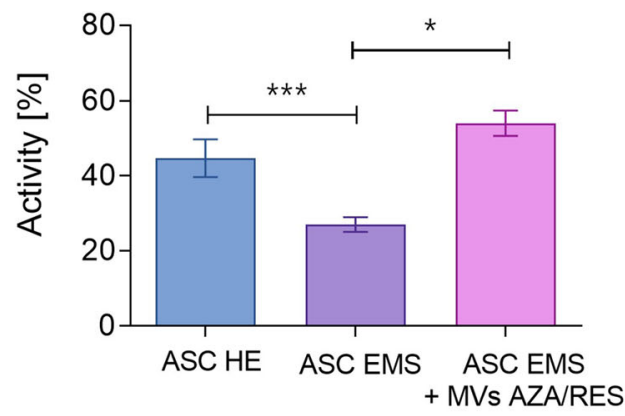


a
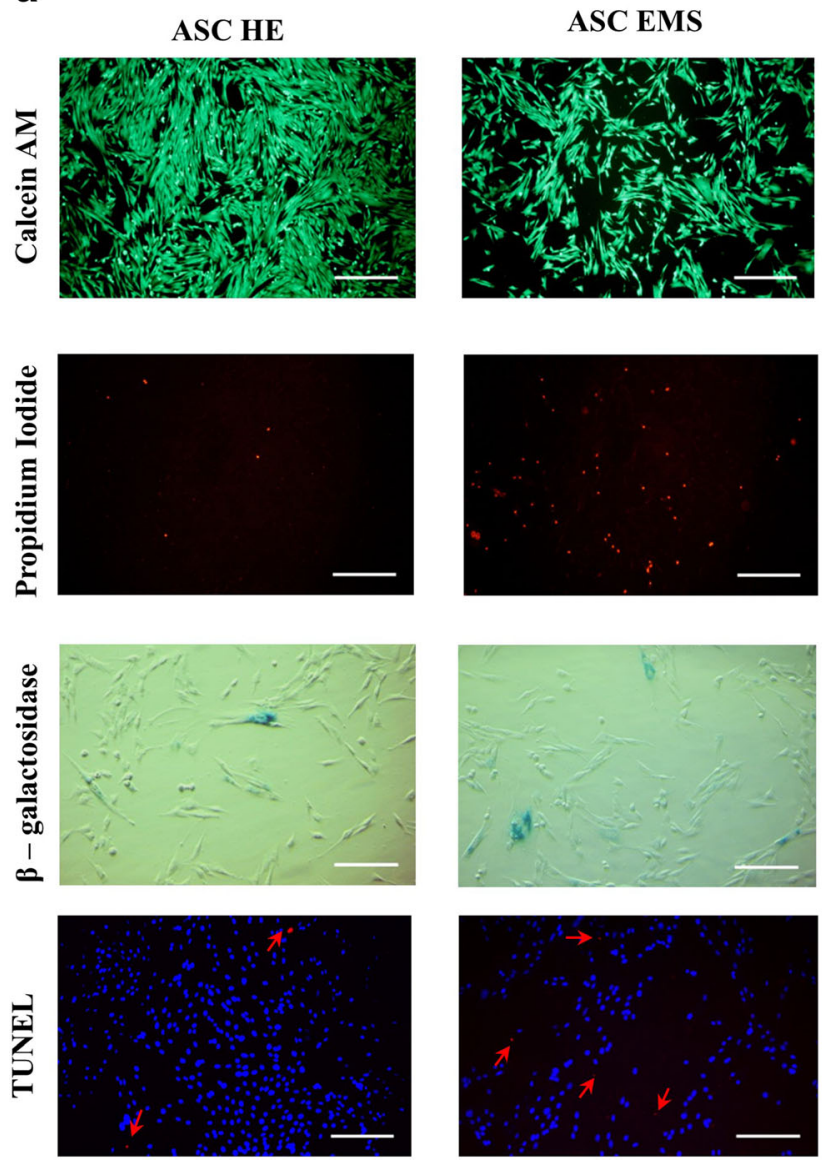

Fig. 2 MVs from AZA/RES treated cells decreased apoptosis and senescence. Stainings for viable (Calcein) and dead cells (Propidium Iodide, TUNEL) (a). Percentage of dead (b) and senescent cells (c) in cultures. Expression of proapoptotic genes: p53 (d), CASP3 (e), CASP9 (f), BAX

upregulated in ASC EMS however, MVs application significantly decreased its expression (Fig. 2d). MVs treatment significantly diminished expression of caspase-3 (CASP3, Fig. 2e), caspase-9 (CASP9, Fig. 2f) and BCL2 associated X protein (BAX, Fig, 2G) in ASC EMS. Expression of BCL2 apoptosis regulator (BCL-2) was decreased in ASC EMS while comparing to control group, however MVs treatment significantly enhanced its expression (Fig. 2h).

\section{Evaluation of ER Stress}

Protein disulphide-isomerase A3 (PDIA3) was visualized in cells using immunofluorescence (Fig. 3a). Its levels was increased in ASC EMS and diminished in cells after MVs treatment. MitoRed staining (Fig. 3b) revealed decreased number of mitochondria in ASC EMS however treatment of cells with MVs restored number of mitochondria in cells. Interestingly, MVs treatment decreased expression of genes that were upregulated in ASC EMS, including Activating transcription factor 6 (ATF-6, Fig. 3c) and Inositol-Requiring kinase 1 (IRE-1, Fig.3d). No differences were observed in the

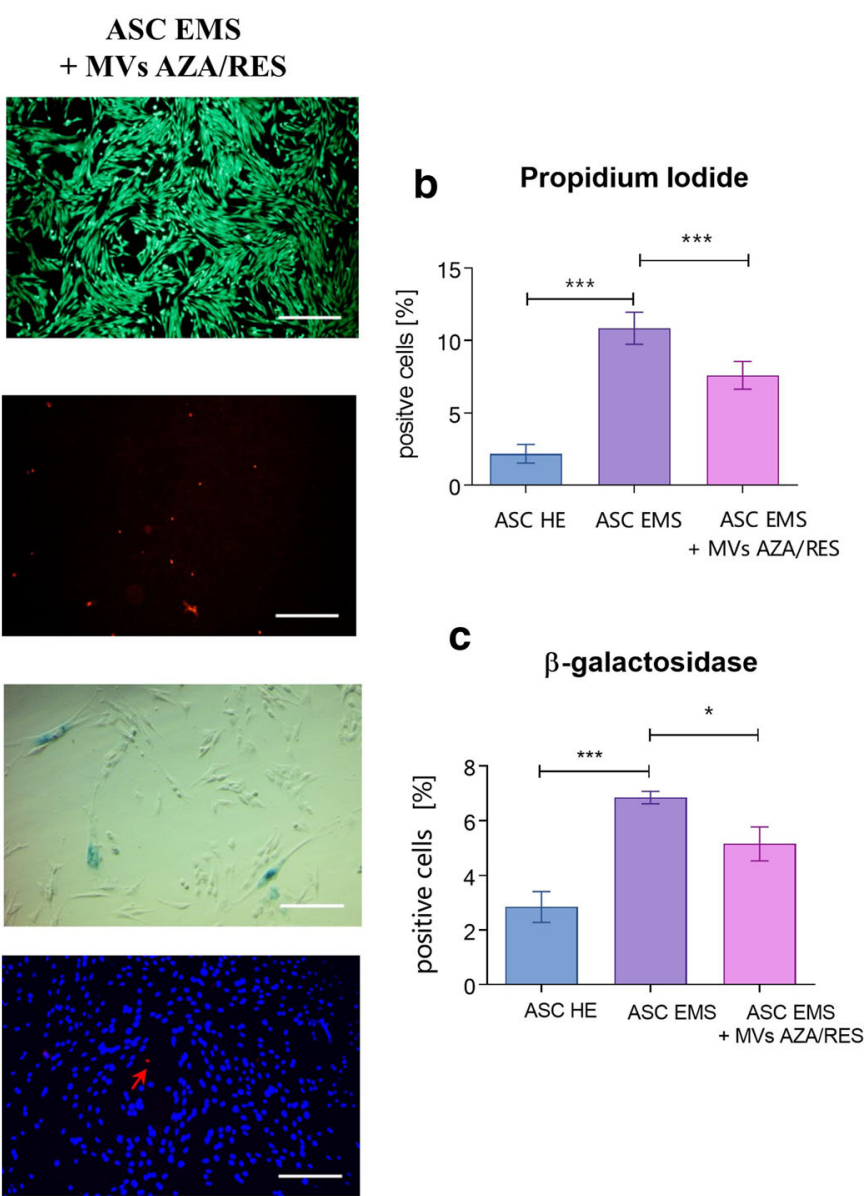

(g) and anti-apoptotic BCL-2 (h). Results expressed as mean \pm SD. $* \mathrm{P}<$ $0.05 ; * * \mathrm{P}<0.01 ; * * * \mathrm{P}<0.001$. $\mathbf{a}-\mathrm{TUNEL} \mathbf{d}, \mathbf{g}$ and $\mathbf{h}$ are reproduced from Kornicka-Garbowska et al. under Creative Commons licence (https://www.ncbi.nlm.nih.gov/pmc/articles/PMC6921487/)

expression of C/EBP Homologous Protein (CHOP, Fig. 3e) before and after MVs application. Administration of MVs decreased expression of Eukaryotic Initiation Factor 2 (EIF2, Fig. 3f) and double-stranded RNA-activated protein kinaselike ER kinase (PERK, Fig. 3g).

\section{Autophagy and Inflammation}

ASC EMS were characterised by increased expression of beclin (Fig. 4a) and Lysosome-associated membrane protein 2 (LAMP-2, Fig. 4b), however application of MVs did not influenced their expression. Significant increase of Phosphoinositide 3-kinase (pi3K, Fig. 4c) expression was observed in ASC EMS and application of MVs decreased its mRNA levels. ELISA results revealed increased levels of extracellular tumor necrosis factor $\alpha$ (TNF $\alpha$, Fig. $4 \mathrm{~d})$ in ASC EMS however MVs application reduced its levels. ELISA for interleukin 10 (IL-10, Fig. 4e) revealed that MVs treatment resulted in its increased secretion by cells. Western blot for interleukin 6 revealed its increased levels in ASC EMS (Fig. 4f). 
d
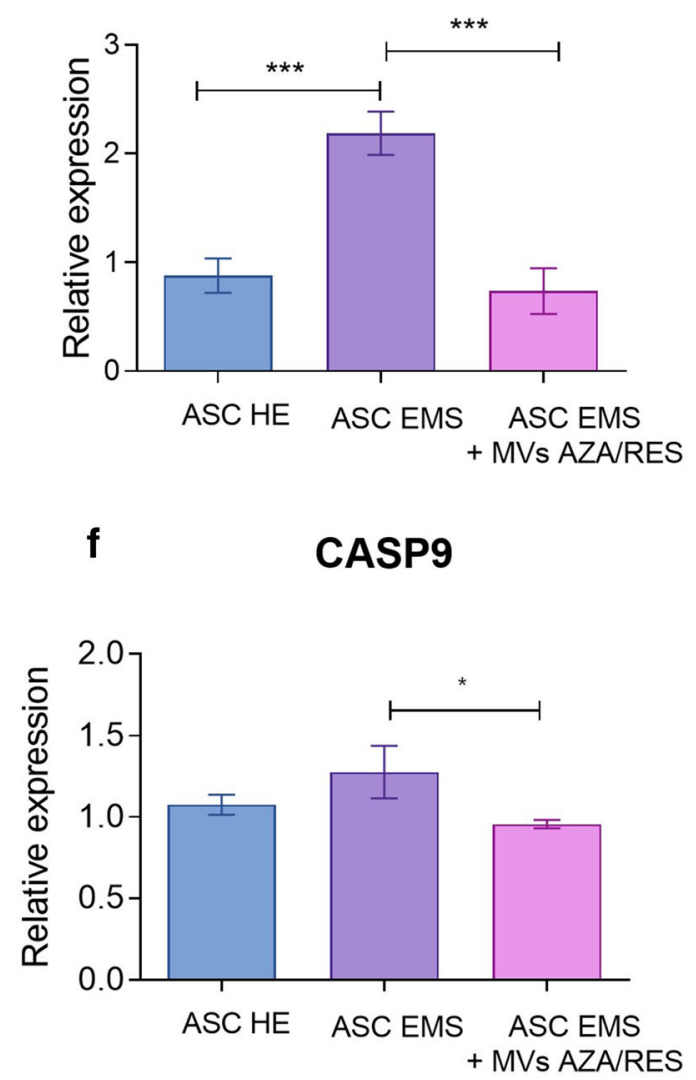

e CASP3

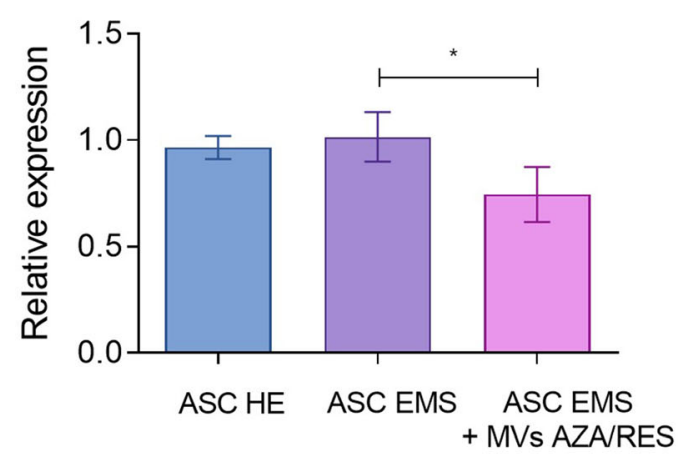

g

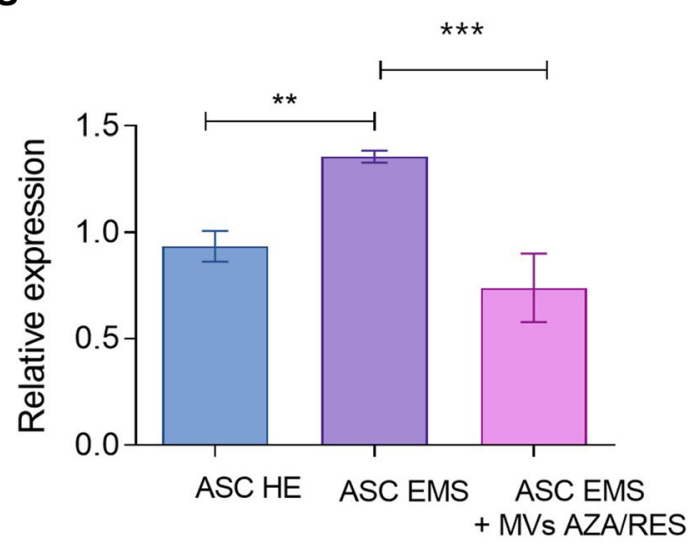

h

BCL-2

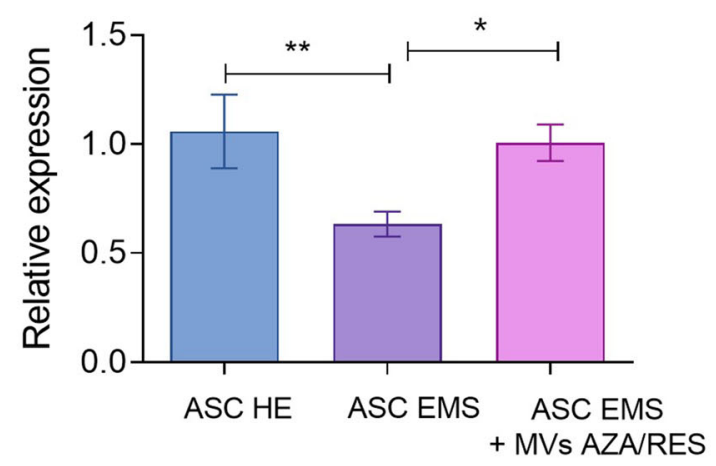

Fig. 2 (continued)

\section{Discussion}

Due to increased prevalence of metabolic disorders in humans and domestic animals, development of novel and effective therapies have become a major goal in the field of regenerative medicine. Among other, adult stem cell therapies hold great promise in the treatment of insulin resistance and obesity- related inflammation. However, multiple research have indicated, that the donors age or health status are directly correlated with so called "pro-regenerative" potential of adult, mesenchymal stem cells [24, 31]. Our and other research findings have indicated, that T2D, MetS as well as EMS negatively affects ASCs multipotency, expansion properties or immunomodulatory effect which undermines their clinical utility $[25$, 
a
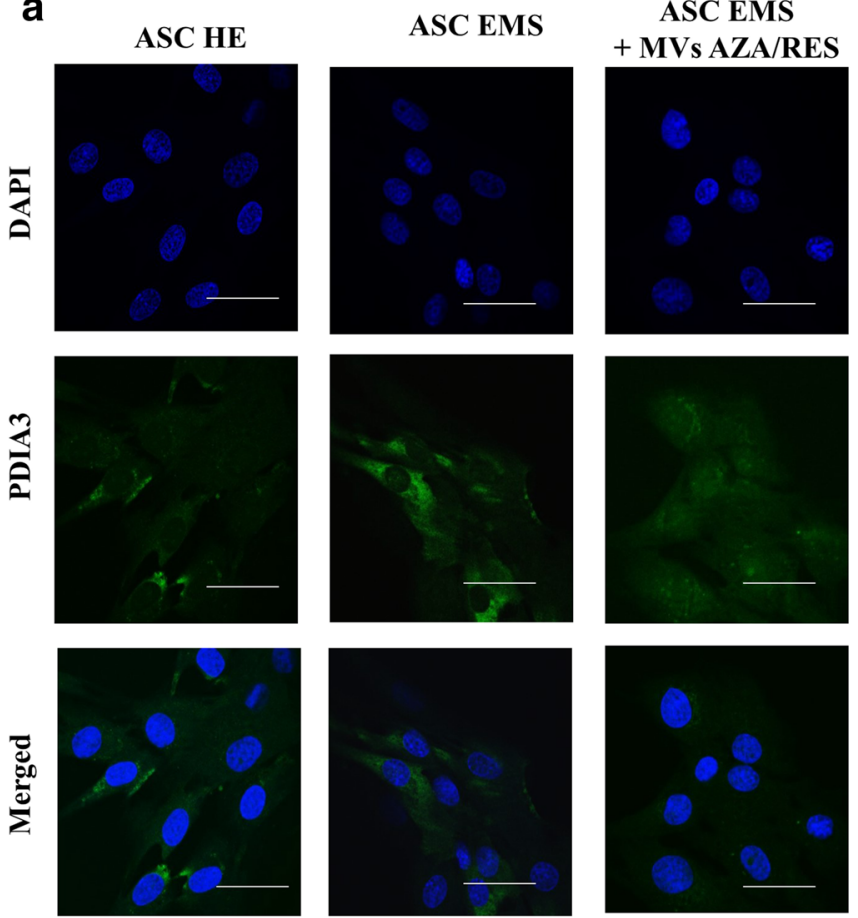

Fig. $3 \mathrm{MVs}$ from AZA/RES treated cells decreased ER stress in metabolic syndrome cells. Immunofluorescent staining for PDIA3 (a) and mitochondrial net visualised with MitoRed dye (b). Expression of genes

32-34]. Moreover, in our previous research we demonstrated, that ASCs isolated form EMS horses are characterized by increased apoptosis and senescence together with mitochondria deterioration induced by enhanced systemic inflammation and excessive oxidative stress [25, 27]. Moreover, the paracrine activity of ASCs isolated form EMS is seriously deteriorated, which disturbs intercellular communication and therefore limits s "stemness" status of cells [25, 27, 29]. So far, several strategies has been proposed to reverse unfavourable phenotype of MSCs affected by dieses including their preincubation with chosen agents before its clinical application. For that purposes, growth factors, vitamins, amino acids or peptides has been proposed $[35,36]$. Recently, we showed, that the combination of AZA/RES reversed aged phenotype of ASCs isolated from EMS (ASCs/EMS) horses- treatment resulted in increased proliferative potential, reduced oxidative stress and improved immunomodulatory properties [27, 29]. In the present study, we showed, that ASCs/EMS preincubated with AZA/RES produce MVs (MVs AZA/RES) of unique biological features. We have found, that $\mathrm{MVs}_{\mathrm{AZA} / \mathrm{RES}}$ positively affect cell viability and improve proliferative activity of ASCs/EMS. Furthermore, the TUNEL staining showed reduced number of dead cells among ASCs/EMS population. We have observed the significant upregulation of antiapoptotic transcript BCL-2 and at the same time reduction of pro-apoptotic gene BAX on mRNA level. This supports the hypothesis, that $\mathrm{MVs}_{\mathrm{AZA} / \mathrm{RES}}$ not only inhibit apoptosis but
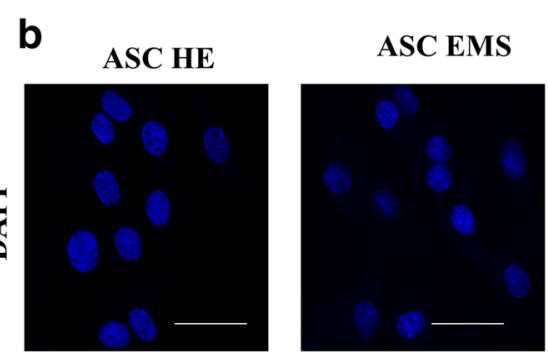

ASC EMS
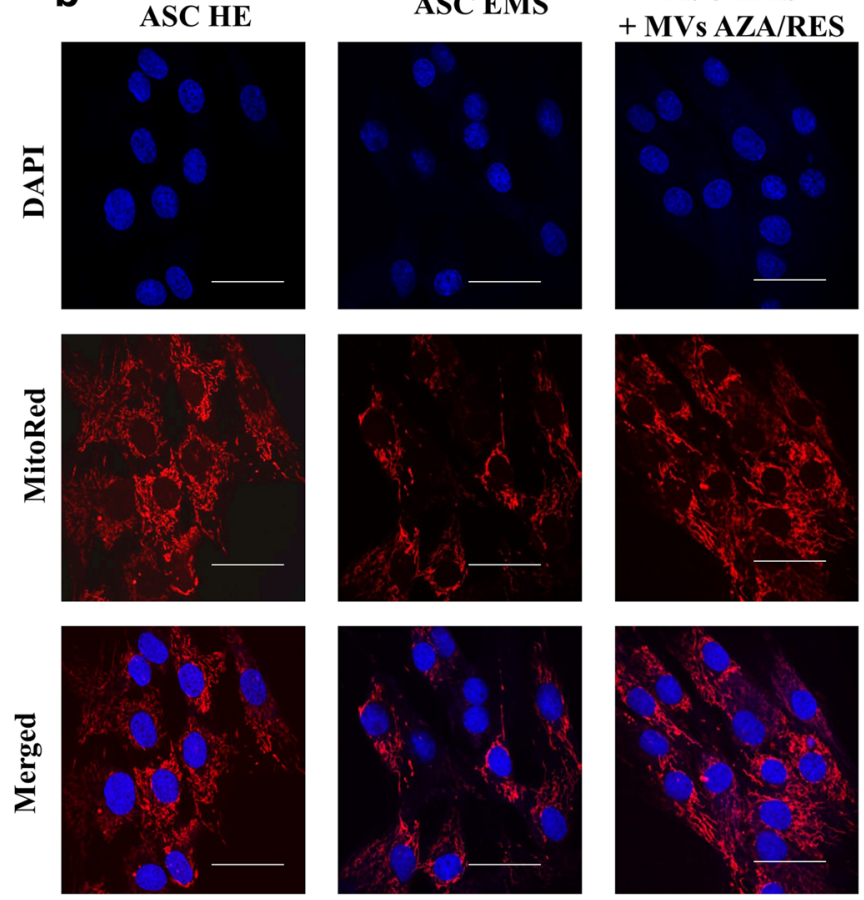

related to ER stress response: ATF-6 (c), IRE-1 (d), CHOP (e), EIF2 (f) and PERK $(\mathbf{g})$. Results expressed as mean $\pm \mathrm{SD}$. $* \mathrm{P}<0.05 ; * * \mathrm{P}<0.01$; $* * * \mathrm{P}<0.001$

also improve viability of physiologically impaired progenitor cells of EMS horses. Similar biological phenomenon was shown in a model of renal ischemia/reperfusion injury where MVs inhibited apoptosis and stimulated cellular proliferation [37]. On the other hand, Herrera et al. [38] demonstrated that in human and rat hepatocytes, MVs enhanced proliferation and decreased apoptosis through mRNA shuttled into recipient cells. Moreover, we have showed, that accumulation of senescence-associated $\beta$-galactosidase is reduced in cells treated with MVsAZA/RES. This stands in good agreement with Bruno et al. [39] who demonstrated, that MSC-derived MVs increases the proliferation rate of tubular epithelial cells after in vitro injury. Moreover, we have demonstrated reduced expression of CASP3 and CASP9, which are the crucial mediators of programmed cell apoptosis especially in the cells affected by hyperinsulinemia. It was demonstrated by Radziszewska et al. [40], that CAP3 knock-out mice were protected from streptozotocin-induced diabetes together with inhibition of B-cells proliferation through inhibition of $\mathrm{p} 27$ transcripts.

Common feature associated with obesity, hyperinsulinemia and insulin resistance in EMS horses is accumulation of oxidative stress factors which leads to excessive, systemic inflammation. In our previous research we showed, that adipose tissue as well as ASC residing within it suffer frm enhanced oxidative stress and inflammation, which impairs their biological 
C

\section{ATF - 6}

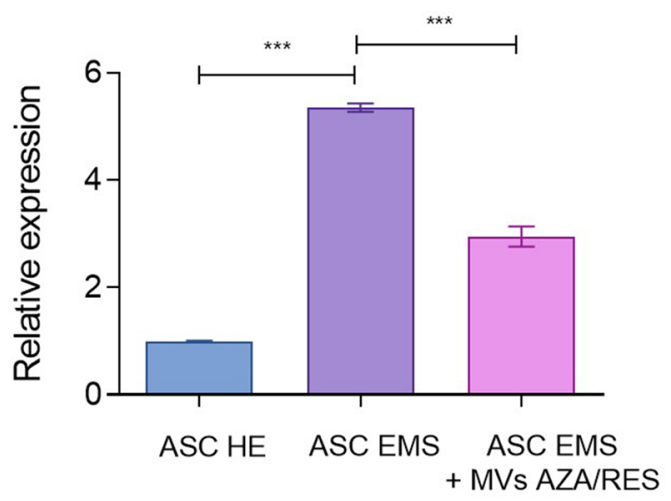

e

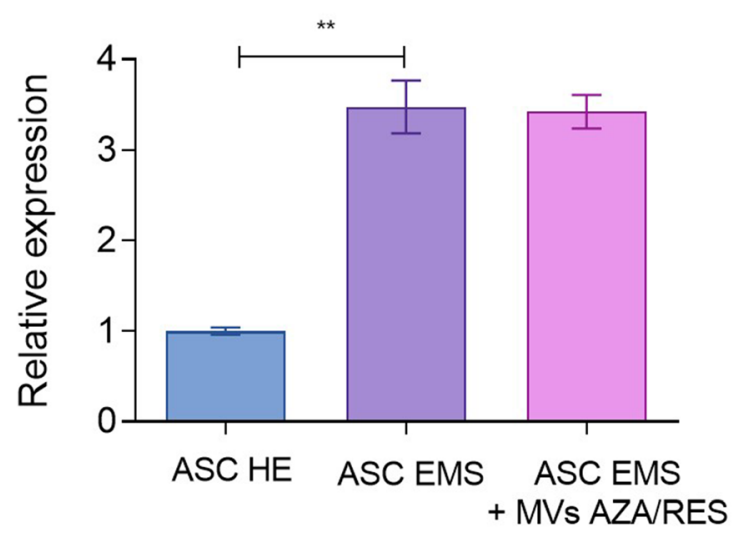

d

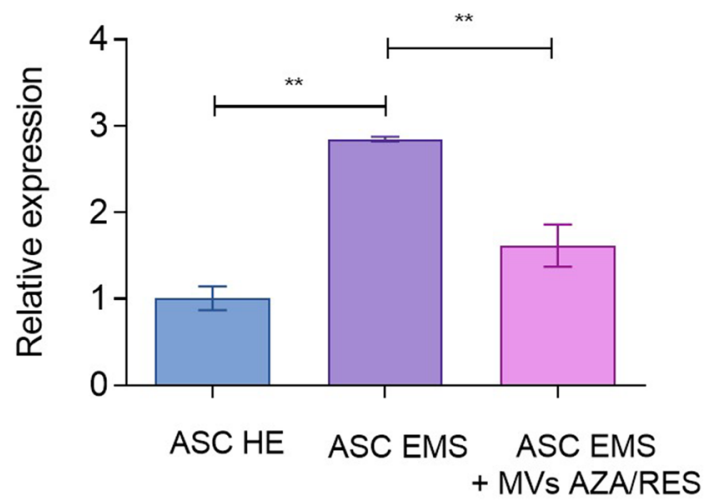

f

\section{EIF2}

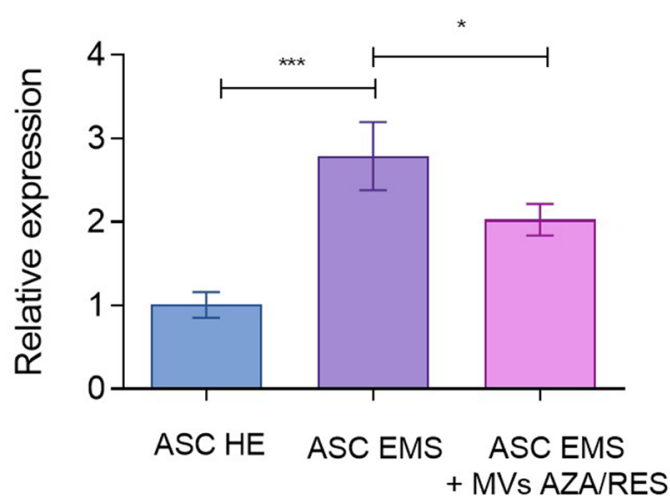

\section{GERK}

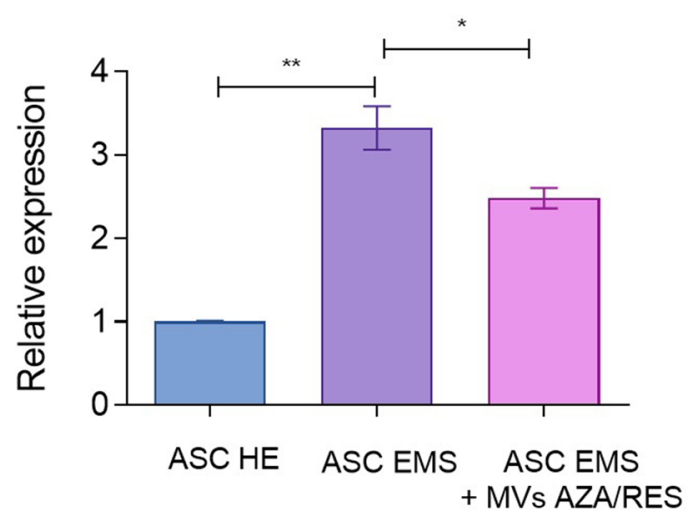

Fig. 3 (continued)

functions [25, 41]. In this study, we showed, that MVsAZA/RES reduce secretion of pro-inflammatory
TNF $\alpha$ while enhance secretion of anti-inflammatory IL-10. Recently, Hosseinkhani et al. [42] demonstrated 
a

Beclin

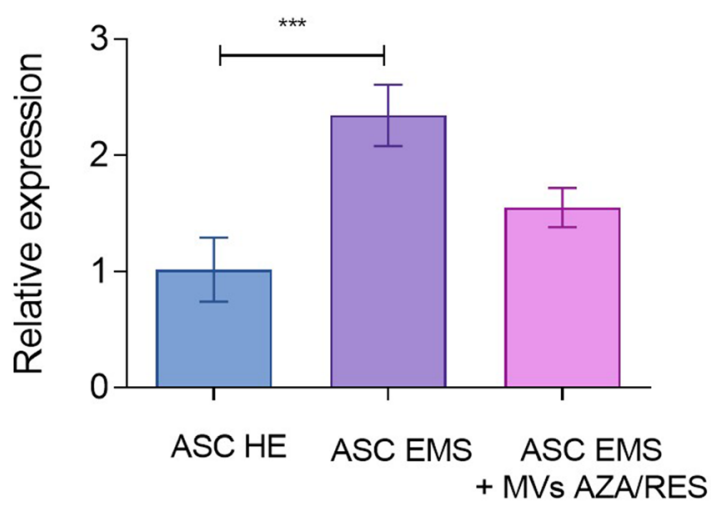

C

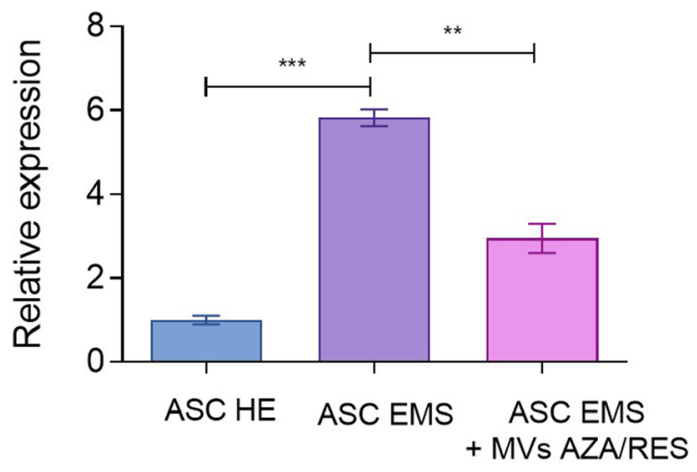

e

\section{IL-10}

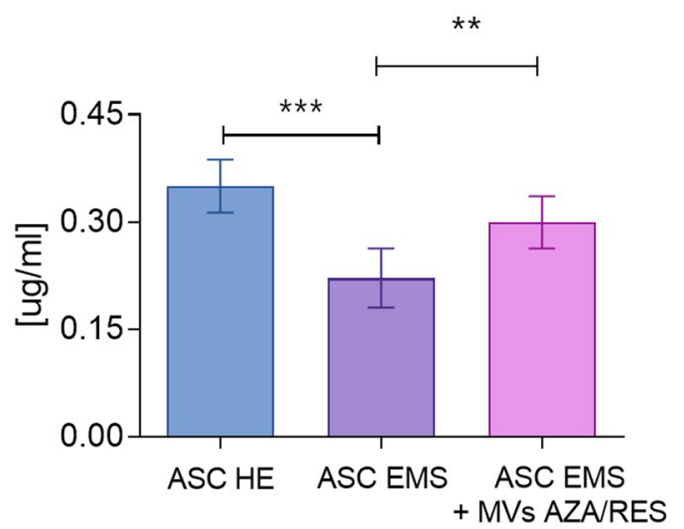

Fig. 4 MVs from AZA/RES decreased autophagy and enhanced secretion of anti-inflammatory cytokines in treated cells. Expression of Beclin (a), LAMP-2 (b) and pi3K (c). Amounts of extracellular TNF $\alpha(\mathbf{d})$ and

immunomodulatory effect of MVs released from endothelial cells in the course of Atherosclerosis - a chronic b

\section{LAMP - 2}

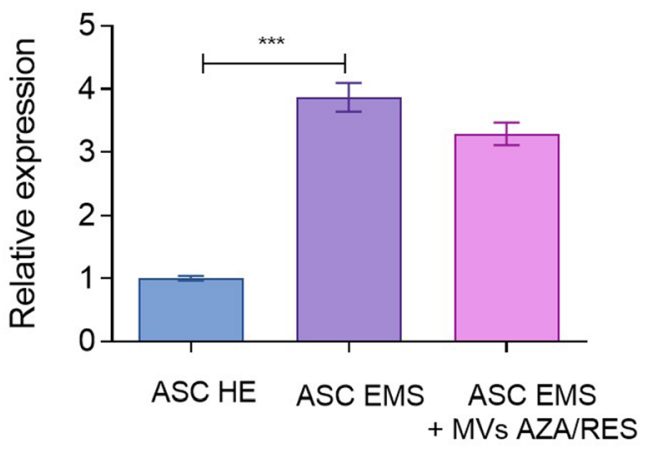

TNF $\alpha$

d

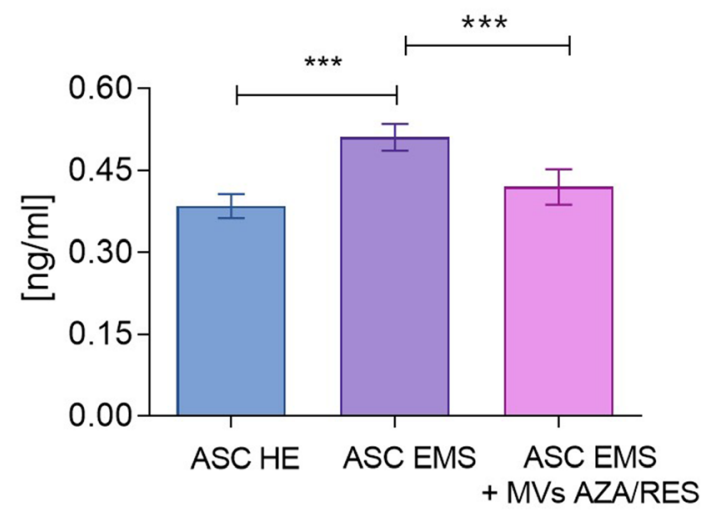

IL-10 (e) established with ELISA. Western blot for IL-6 (f). Results expressed as mean $\pm \mathrm{SD}$. $* \mathrm{P}<0.05 ; * * \mathrm{P}<0.01 ; * * * \mathrm{P}<0.001$

and progressive inflammatory vascular disorder. Similar phenomenon was observed by Harrell et al. [43] who 
showed, that both local and systemic administration of MSC derived MVs efficiently suppress detrimental immune response in inflamed tissues and promote survival and regeneration of injured parenchymal cells. Additionally, by transfer of mRNA and miRNA for target cells, extracellular microvesicles promote cells survival and regenerative properties by reducing necrosis associated with oxidative stress [43]. As recently showed by our group, ASC/EMS displayed decreased proliferation rate, increased apoptosis and senescence together with mitochondria deterioration [27]. The impairment of mitochondrial biogenesis and dynamics is directly associated with deterioration of cellular function including multipotency and immune modulation [28, 29]. Numerous studies including ours, have shown that autophagy as well as mitophagy, serve as a protective mechanisms, allowing deteriorated ASC/EMS survive and maintain basic cellular functions under stress condition [27, 44, 45]. Here, for the first time we have shown that MVsAZA/RES reduce expression of transcripts involved in autophagy including LAMP-or Beclin-1. It might be explained by their anti-oxidative activity, since we observed elevated amount of SOD together with reduced ROS and NO - the master inducers of oxidative stress. Similar effect was noted by Harrell et al. [43] who showed, that MVs transferred to the target cells- injured hepatocytes, neurons and lung cells activate autophagy, inhibits apoptosis, necrosis and oxidative stress and therefore promote cellular survival and regeneration. Furthermore, it was showed, that excessive oxidative stress combined with lipo- and glucotoxicity significantly contribute to the development of ER stress [31, 46]. In the present study, we showed, that MVsAZA/RES reduce ER stress as we observed decreased expression of following transcripts ATF-6, IRE-1, PERK, EIF2 and CHOP. Similar effect was found by Liao et al. [47], who showed, that MVs could attenuate ER stress-induced apoptosis by activating AKT and ERK signaling. More recently, Chen et al. [48], showed that MSC derived MVs protects beta cells against hypoxia-induced apoptosis via miR-21 by alleviating ER stress and inhibiting p38 MAPK phosphorylation.

Recent findings in stem cells have shed a promising light for the application of their extracellular vesicles in the treatment of different disorders. In present study we showed, that ASCs/EMS preincubated with AZA/RES promote secretion of MVs that are able to reduce oxidative stress, inflammation and ER stress and thus protect recipient cells against apoptosis and senescence. However, further research are strongly required to understand the mechanism involved in regenerative processes and therapeutic potential of MV's in the course of different disorders including EMS, T2D and MetS.

\section{Materials and Methods}

All reagents and chemicals used in this research were purchased from Sigma-Aldrich (Poznań, Poland), unless indicated otherwise.

\section{Tissue Harvesting}

Adipose tissue samples were harvested from the group of healthy horses $(n=15)$, and horses diagnosed with EMS. Animals were mixed sex and age - matched (8-12 years). Qualification of animals to selected group was performed on the basis of following parameters: body weight, body condition score, cresty neck score, existing laminitis, resting insulin levels, blood glucose levels, oral sugar test. Detailed characterisation of horses can be found in our previous paper [27].

\section{Cell Isolation and Characterisation}

Samples of subcutaneous adipose tissue were harvested from the animal's tail base. ASCs were isolated as descried previously [27] using enzymatic method (collagenase type I in a concentration of $1 \mathrm{mg} / \mathrm{mL}$ for $40 \mathrm{~min}$ at $37^{\circ} \mathrm{C}$ ) from healthy (ASC HE) and EMS horses (ASC EMS). Cells were cultured in Dulbecco's Modified Eagle's Medium (DMEM) Low Glucose supplemented with $10 \%$ of foetal bovine serum (FBS) and $1 \%$ of penicillin/streptomycin (PS) solution. Media were changed every 2-3 days. Cells were passaged after reaching $80 \%$ confluence using trypsin solution (TrypLE; Life Technologies, Carlsbad, CA, USA). Cells were characterised by the presence of CD44, CD45 and CD90 surface antigens using Becton Dickinson FACS Calibur Flow Cytometer as shown previously [27]. Additionally, osteogenic, chondrogenic and adipogenic differentiation of isolated cells was confirmed as well [27].

\section{Isolation of MVs}

MVs were isolated with ultracentrifuge as described elsewhere [30]. Procedure scheme is shown in Fig. 1. In order to isolate MVs from ASC-EMS, cells were cultured with $0.5 \mu \mathrm{M}$ of AZA and $0.05 \mu \mathrm{M}$ of RES for $24 \mathrm{~h}$ as described previously [27]. Next, the medium was replaced with serum free culture medium supplemented with $1 \%$ of PS for an additional $24 \mathrm{~h}$. After that, medium was collected and subjected to centrifugation at $300 \mathrm{xg}$ for $10 \mathrm{~min}$. Supernatant was collected and centrifuged at $2000 \mathrm{xg}$ for $10 \mathrm{~min}$. After that, supernatant was collected again and centrifuged in ultracentrifuge at $20000 \mathrm{xg}$ for $30 \mathrm{~min}$. The amount of MVs in obtained pellet was verified with BCA Protein Assay. 


\section{Experimental Setting}

In order to perform the experiments, cells were seeded in cells were seeded $24-$ well plates at the density of $3 \times 10^{4}$ per well. After $24 \mathrm{~h}$, in the experimental group medium was replaced for culture medium supplemented with MVs derived from ASC-EMS AZA/RES treated cells at the concentration of 25 $\mu \mathrm{g} / \mathrm{ml}$. After $24 \mathrm{~h}$ of incubation cells were collected and subjected for further analysis.

\section{Proliferation Rate}

In order to select most potent concentration of MVs, cells were cultured with 5 different MVs concentration for $24 \mathrm{~h}$. Cell viability was evaluated using $10 \%$ resazurin-based dyeTOX-8 in accordance with manufacturer protocol, after 24 , 48,72 and $96 \mathrm{~h}$ of propagation. In order to perform the assay cells were incubated with dye in a $\mathrm{CO}_{2}$ incubator, $37^{\circ} \mathrm{C}$ for $2 \mathrm{~h}$ and then supernatants absorbance was measured (Epoch, BioTek) at a wavelength of $600 \mathrm{~nm}$ for resazurin and $690 \mathrm{~nm}$ reference wavelength. Proliferation potential was established by the analysis of BrdU incorporation using BrdU Cell Proliferation ELISA Kit (Abcam) in accordance with manufacturer's instructions. Briefly, cells were first incubated with anti-BrdU antibody and then with horseradish peroxidase (HRP)-conjugated goat anti-mouse antibody. Colorimetric reaction was induced by the conversion of the chromogenic substrate tetra-methylbenzidine (TMB) and the absorbance was measured using the spectrophotometer (Epoch, BioTek) at $450 \mathrm{~nm}$ and $550 \mathrm{~nm}$ as the length for the reference wave.

\section{Evaluation of Apoptosis and Senescence}

Live and dead cells in cultures were visualized using Cellstain Double Staining Kit in accordance with manufacturers protocol. Viable cells were stained with Calcein-AM (green fluorescence), whereas dead cells' nuclei were stained with Propidium Iodide (orange fluorescence). Cells were then observed using fluorescence microscopy (Zeiss, Axio Observer A.1). The percentage of dead cells was calculated.

Prior identification of senescence associated $\beta$ galactosidase ( $\beta$-gal), cells were stained using a Senescence Cells Histochemical Staining Kit (Sigma Aldrich) in accordance with manufacturer's protocol. Cells were then observed under an inverted microscope (Zeiss, Axio Observer A.1) and percentage of $\beta$-gal (stained blue) positive cells in regard to $\beta$ gal negative cells was calculated.

\section{Evaluation of Oxidative Stress Factors}

Nitric oxide (NO) concentration was assessed using commercially available Griess reagent kit (Life Technologies). Superoxide dismutase (SOD) activity was measured using a
SOD Assay kit (Sigma Aldrich). Reactive oxygen species (ROS) were estimated by incubating cells with an H2DCFDA (Life Technologies) solution. All procedures were performed according to manufacturer's protocols.

\section{Evaluation of TNF- $a$ and IL-10}

The amounts of extracellular TNF- $\alpha$ and IL-10 in culture media was investigated with ELISA assays- horse tumour necrosis factor (TNF superfamily, member 2) ELISA Kit (MyBioSource, San Diego, CA, USA) and horse Interleukin-10 ELISA Kit (MyBioSource, San Diego, CA, USA). All procedures were performed in accordance with manufacturers protocols.

\section{Visualization of Mitochondrial Net and ER}

Mitochondrial network inside the cells was visualized using MitoRed staining. Briefly, dye solution (1:000) was added to culture media and cells were incubated for $30 \mathrm{~min}$ in $\mathrm{CO}_{2}$ incubator. Then specimens were fixed with $4 \% \mathrm{PFA}$ and nuclei were counterstained with DAPI.

ER was visualised in cells using immunofluorescent staining for PDIA3. Briefly, cells were fixed $4 \%$ PFA, permeabilized with $0,5 \%$ Triton $\mathrm{X}-100$ for $20 \mathrm{~min}$ and incubated with blocking buffer (10\% Goat Serum, $0.2 \%$ Tween-20 in PBS). Next, specimens were kept in $4{ }^{\circ} \mathrm{C}$ with primary antibodies against PDIA3 (Abcam) diluted 1:1000 in PBS containing 1\% Goat Serum and 0.2\% Tween-20. Prior observations, secondary antibodies conjugated with atto-488 (dilution 1:1000, Abcam) were applied and nuclei were counterstained with DAPI. Cells were observed and photographed with a confocal microscope (Observer Z1 Confocal Spinning Disc V.2 Zeiss).

\section{Gene Expression}

Total RNA was isolated from cells using TriReagent in accordance with manufacturers protocol. RNA concentrations and quality were evaluated using nanospectrophotometer (Epoch, BioTek). Total RNA was reversely transcribed into cDNA using the First Strand cDNA Synthesis Kit was used (Thermo Fisher Scientific, USA). Gene expression was evaluated using SensiFast SYBR \&Fluorescein Kit (Bioline, UK). T100 Thermal Cycler (Bio-Rad, USA) was used to carry out all the amplifications and detections. The $2-\Delta \Delta \mathrm{CT}$ algorithm was used to calculate the value transcripts in relation to the expression of the reference gene-GAPDH. Primers are listed in supplementary file. 


\section{Western Blotting}

Cells were rinsed in ice-cold PBS and extracts were prepared in RIPA buffer supplemented with protease inhibitor (1:1000). Then lysates were subjected to SDS-PAGE and transferred to polyvinylidene difluoride (PVDF) membrane (BioRad). The following antibodies were used for immunoblotting: B-Actin (1:1000, Sigma Aldrich) and IL-6 (1:250, Abcam) at dilution for in in 5\% non-fat milk in Tris/Nacl/ Tween buffer (TBST). Then membranes were incubated with anti-rabbit and anti-mouse horseradish peroxidase-conjugated secondary antibodies. Reactions were developed using Western HRP Substrate (Millipore Corporation). Chemiluminescent signals were detected using ChemiDoc MP Imaging System (Bio-Rad, USA) and quantified with Image Lab Software (Bio-Rad, USA).

\section{Statistic}

All experiments were performed at least in three replicates. Differences between experimental groups was estimated using the one-way ANOVA with Tukey's test. Statistical analysis was conducted with GraphPad Prism Software (La Jolla, CA, USA). Differences were considered statistically significant at $* p<0.05, * * p<0.01$, and $* * * p<0.001$.

Acknowledgements This project was financed within the framework of a grants entitled "Modulation mitochondrial metabolism and dynamics and targeting DNA methylation of adipose derived mesenchymal stromal stem cell (ASC) using resveratrol and 5-azacytydin as a therapeutic strategy in the course of Equine metabolic syndrome (EMS)." (grant no. 2016/21/B/NZ7/01111) and "Inhibition of tyrosine phosphatase as a strategy to enhance insulin sensitivity through activation of chaperone mediated autophagy and amelioration of inflammation and cellular stress in the liver of equine metabolic syndrome (EMS) horses." (grant no. 2018/29/B/ NZ7/02662) financed by The National Science Centre in Poland.

Authors' Contributions K.M. and K.K.G designed the research. K.K., M.M, PS, CW conducted the research. P.S. C.W. M.M analyzed data. K.M., CW and K.K. wrote the paper and prepared the figures K.M. contributed reagents/materials/analysis tools. All authors read and approved the final manuscript.

\section{Compliance with Ethical Standards}

Conflict of Interest Authors declare that there is no conflict of interest

Open Access This article is licensed under a Creative Commons Attribution 4.0 International License, which permits use, sharing, adaptation, distribution and reproduction in any medium or format, as long as you give appropriate credit to the original author(s) and the source, provide a link to the Creative Commons licence, and indicate if changes were made. The images or other third party material in this article are included in the article's Creative Commons licence, unless indicated otherwise in a credit line to the material. If material is not included in the article's Creative Commons licence and your intended use is not permitted by statutory regulation or exceeds the permitted use, you will need to obtain permission directly from the copyright holder. To view a copy of this licence, visit http://creativecommons.org/licenses/by/4.0/.

\section{References}

1. Marycz, K., Szłapka-Kosarzewska, J., Geburek, F., \& KornickaGarbowska, K. (2019). Systemic administration of rejuvenated adipose-derived mesenchymal stem cells improves liver metabolism in equine metabolic syndrome (EMS)- new approach in veterinary regenerative medicine. Stem Cell Reviews and Reports, 15, 842-850. https://doi.org/10.1007/s12015-019-09913-3.

2. Therapeutic mesenchymal stromal stem cells: Isolation, characterization and role in equine regenerative medicine and metabolic disorders | SpringerLink Available online: https://link.springer.com/ article/10.1007/s12015-019-09932-0 (accessed on Apr 10, 2020).

3. Frank, N. (2009). Equine metabolic syndrome. J. Equine Vet. Sci., 29, 259-267. https://doi.org/10.1016/j.jevs.2009.04.183.

4. Merlo, B., Teti, G., Mazzotti, E., Ingrà, L., Salvatore, V., Buzzi, M., Cerqueni, G., Dicarlo, M., Lanci, A., Castagnetti, C., \& Iacono, E. (2018). Wharton's jelly derived mesenchymal stem cells: Comparing human and horse. Stem Cell Reviews and Reports, 14, 574-584. https://doi.org/10.1007/s12015-018-9803-3.

5. Telugu, B. P. V. L., Ezashi, T., \& Roberts, R. M. (2010). The promise of stem cell research in pigs and other ungulate species. Stem Cell Reviews and Reports, 6, 31-41. https://doi.org/10.1007/ s12015-009-9101-1.

6. Rogers, C. S. (2016). Engineering large animal species to model human diseases. Curr Protoc Hum Genet Editor Board Jonathan Haines Al, 90, 15.9.1-15.9.14. https://doi.org/10.1002/cphg.18.

7. Marędziak, M., Śmieszek, A., Chrząstek, K., Basinska, K., \& Marycz, K. (2015). Physical Activity Increases the Total Number of Bone-Marrow-Derived Mesenchymal Stem Cells, Enhances Their Osteogenic Potential, and Inhibits Their Adipogenic Properties. Stem Cells International. Research article. https://doi. org/10.1155/2015/379093

8. Marycz, K., Mierzejewska, K., Ś, Mieszek, A., Suszynska, E., Malicka, I., Ratajczak, M. Z. (2016). Endurance Exercise Mobilizes Developmentally Early Stem Cells into Peripheral Blood and Increases Their Number in Bone Marrow: Implications for Tissue Regeneration. Stem Cells International. Research article. https://doi.org/10.1155/2016/5756901

9. Marycz, K., Grzesiak, J., Wrzeszcz, K., \& Golonka, P. (2012). Adipose stem cell combined with plasma-based implant bone tissue differentiation in vitro and in a horse with a phalanx digitalis distalis fracture: a case report. Veterinarni Medicina (Czech Republic). Retrieved from http://agris.fao.org/agris-search/search.do? recordID $=$ CZ2013000199

10. Karamini, A., Bakopoulou, A., Andreadis, D., Gkiouras, K., \& Kritis, A. (2020). Therapeutic potential of Mesenchymal stromal stem cells in rheumatoid arthritis: A systematic review of in vivo studies. Stem Cell Reviews and Reports, 16, 276-287. https://doi. org/10.1007/s12015-020-09954-z.

11. Zafardoust, S., Kazemnejad, S., Darzi, M., Fathi-Kazerooni, M., Rastegari, H., \& Mohammadzadeh, A. (2020). Improvement of pregnancy rate and live birth rate in poor ovarian responders by Intraovarian Administration of Autologous menstrual blood derived- mesenchymal stromal cells: Phase I/II clinical trial. Stem Cell Reviews and Reports, 16, 755-763. https://doi.org/10.1007/ s12015-020-09969-6.

12. Cislo-Pakuluk, A., \& Marycz, K. (2017). A Promising Tool in Retina Regeneration: Current Perspectives and Challenges When Using Mesenchymal Progenitor Stem Cells in Veterinary and 
Human Ophthalmological Applications. Stem Cell Reviews, 13(5), 598-602. https://doi.org/10.1007/s12015-017-9750-4

13. Nawrocka, D., Kornicka, K., Śmieszek, A., \& Marycz, K. (2017). Spirulina platensis Improves Mitochondrial Function Impaired by Elevated Oxidative Stress in Adipose-Derived Mesenchymal Stromal Cells (ASCs) and Intestinal Epithelial Cells (IECs), and Enhances Insulin Sensitivity in Equine Metabolic Syndrome (EMS) Horses. Marine Drugs, 15(8). https://doi.org/10.3390/ md15080237

14. Marycz, K., Kornicka, K., Grzesiak, J., Ś, Mieszek, A., Szł, \& Apka, J. (2016). Macroautophagy and Selective Mitophagy Ameliorate Chondrogenic Differentiation Potential in Adipose Stem Cells of Equine Metabolic Syndrome: New Findings in the Field of Progenitor Cells Differentiation. Oxidative Medicine and Cellular Longevity. Research article. https://doi.org/10.1155/2016/ 3718468

15. Boháčová, P., \& Holáň, V. (2018). Mesenchymal stem cells and type 1 diabetes treatment. Vnitrni Lékarství, 64, 725-728.

16. Pileggi, A. (2012). Mesenchymal stem cells for the treatment of diabetes. Diabetes, 61, 1355-1356. https://doi.org/10.2337/db120355 .

17. Ratajczak, J., Wysoczynski, M., Hayek, F., Janowska-Wieczorek, A., \& Ratajczak, M. Z. (2006). Membrane-derived microvesicles: Important and underappreciated mediators of cell-to-cell communication. Leukemia, 20, 1487-1495. https://doi.org/10.1038/sj.leu. 2404296.

18. Akyurekli, C., Le, Y., Richardson, R. B., Fergusson, D., Tay, J., \& Allan, D. S. (2015). A systematic review of preclinical studies on the therapeutic potential of Mesenchymal stromal cell-derived microvesicles. Stem Cell Reviews and Reports, 11, 150-160. https://doi.org/10.1007/s12015-014-9545-9.

19. Biancone, L., Bruno, S., Deregibus, M. C., Tetta, C., \& Camussi, G. (2012). Therapeutic potential of mesenchymal stem cell-derived microvesicles. Nephrol Dial. Transplant. Off. Publ. Eur. Dial. Transpl. Assoc. - Eur. Ren. Assoc., 27, 3037-3042. https://doi. org/10.1093/ndt/gfs168.

20. Kornicka-Garbowska, K., Pędziwiatr, R., Woźniak, P., Kucharczyk, K., \& Marycz, K. (2019). Microvesicles isolated from 5 -azacytidine-and-resveratrol-treated mesenchymal stem cells for the treatment of suspensory ligament injury in horse-A case report. Stem Cell Research \& Therapy, 10, 394. https://doi.org/10. 1186/s13287-019-1469-5.

21. Collino, F., Deregibus, M. C., Bruno, S., Sterpone, L., Aghemo, G., Viltono, L., Tetta, C., \& Camussi, G. (2010). Microvesicles derived from adult human bone marrow and tissue specific Mesenchymal stem cells shuttle selected pattern of miRNAs. PLoS One, 5, e11803. https://doi.org/10.1371/journal.pone.0011803.

22. Ratajczak, J., Miekus, K., Kucia, M., Zhang, J., Reca, R., Dvorak, P., \& Ratajczak, M. Z. (2006). Embryonic stem cell-derived microvesicles reprogram hematopoietic progenitors: Evidence for horizontal transfer of mRNA and protein delivery. Leukemia, 20, 847-856. https://doi.org/10.1038/sj.leu.2404132.

23. Camussi, G., Deregibus, M. C., Bruno, S., Cantaluppi, V., \& Biancone, L. (2010). Exosomes/microvesicles as a mechanism of cell-to-cell communication. Kidney International, 78, 838-848. https://doi.org/10.1038/ki.2010.278.

24. Kornicka, K., Houston, J., \& Marycz, K. (2018). Dysfunction of mesenchymal stem cells isolated from metabolic syndrome and type 2 diabetic patients as result of oxidative stress and autophagy may limit their potential therapeutic use. Stem Cell Reviews and Reports, 14, 1-9. https://doi.org/10.1007/s12015-018-9809-x.
25. Marycz, K.; Kornicka, K.; Basinska, K.; Czyrek, A. (2017) Equine metabolic syndrome affects viability, senescence, and stress factors of equine adipose-derived mesenchymal stromal stem cells: New insight into EqASCs Isolated from EMS horses in the context of their aging available online: https://www.hindawi.com/journals/ omcl/2016/4710326/. Accessed 10 Nov 2016

26. Marycz, K.; Kornicka, K.; Grzesiak, J.; Śmieszek, A.; Szłapka, J. (2019) Macroautophagy and selective mitophagy ameliorate chondrogenic differentiation potential in adipose stem cells of equine metabolic syndrome: New findings in the field of progenitor cells differentiation available online: https://www.hindawi.com/ journals/omcl/2016/3718468/. Accessed 27 Jun 2016.

27. Kornicka, K., Szłapka-Kosarzewska, J., Śmieszek, A., \& Marycz, K. (2019). 5-Azacytydine and resveratrol reverse senescence and ageing of adipose stem cells via modulation of mitochondrial dynamics and autophagy. Journal of Cellular and Molecular Medicine, 23, 237-259. https://doi.org/10.1111/jcmm.13914.

28. Marycz, K., Kornicka, K., Irwin-Houston, J. M., \& Weiss, C. (2018). Combination of resveratrol and 5-azacytydine improves osteogenesis of metabolic syndrome mesenchymal stem cells. Journal of Cellular and Molecular Medicine, 22, 4771-4793. https://doi.org/10.1111/jcmm.13731.

29. Kornicka, K.; Śmieszek, A.; Węgrzyn, A.S.; Röcken, M.; Marycz, K. Immunomodulatory properties of adipose-derived stem cells treated with 5-azacytydine and resveratrol on peripheral blood mononuclear cells and macrophages in metabolic syndrome animals. Journal of Clinical Medicine 2018, 7, doi:https://doi.org/10. 3390/jcm7110383, 7.

30. Szatanek, R., Baran, J., Siedlar, M., \& Baj-Krzyworzeka, M. (2015). Isolation of extracellular vesicles: Determining the correct approach (review). International Journal of Molecular Medicine, 36, 11-17. https://doi.org/10.3892/ijmm.2015.2194.

31. Alicka, M., \& Marycz, K. (2018). The effect of chronic inflammation and oxidative and endoplasmic reticulum stress in the course of metabolic syndrome and its therapy. Stem Cells International, 2018, 1-13. https://doi.org/10.1155/2018/4274361.

32. Alicka, M., Major, P., Wysocki, M., \& Marycz, K. (2019). Adipose-derived mesenchymal stem cells isolated from patients with type 2 diabetes show reduced "Stemness" through an altered secretome profile, impaired anti-oxidative protection, and mitochondrial dynamics deterioration. Journal of Clinical Medicine, 8, 8. https://doi.org/10.3390/jcm8060765.

33. Kornicka, K., Marycz, K., Tomaszewski, K. A., Marędziak, M., \& Śmieszek, A. (2015). The effect of age on osteogenic and adipogenic differentiation potential of human adipose derived stromal stem cells (hASCs) and the impact of stress factors in the course of the differentiation process. Oxidative Medicine and Cellular Longevity, 2015, 309169-309120. https://doi.org/10.1155/2015/ 309169.

34. Stolzing, A., Jones, E., McGonagle, D., \& Scutt, A. (2008). Agerelated changes in human bone marrow-derived mesenchymal stem cells: Consequences for cell therapies. Mechanisms of Ageing and Development, 129, 163-173. https://doi.org/10.1016/j.mad.2007. 12.002 .

35. Honoki, K. (2017). Preventing aging with stem cell rejuvenation: Feasible or infeasible? World J. Stem Cells, 9, 1-8. https://doi.org/ 10.4252/wjsc.v9.i1.1.

36. Wang, M., Chen, J., Chen, F., Liu, Q., Sun, Y., Yan, C., Yang, T., Bao, Y., \& Hu, Y.-P. (2019). Rejuvenating strategies of tissuespecific stem cells for healthy aging. Aging and Disease, 10, 871882. https://doi.org/10.14336/AD.2018.1119. 
37. Jiang, X., Lew, K.-S., Chen, Q., Richards, A. M., \& Wang, P. (2018). Human mesenchymal stem cell-derived exosomes reduce ischemia/reperfusion injury by the inhibitions of apoptosis and autophagy. Current Pharmaceutical Design, 24, 5334-5341. https:// doi.org/10.2174/1381612825666190119130441.

38. Herrera, M. B., Fonsato, V., Gatti, S., Deregibus, M. C., Sordi, A., Cantarella, D., Calogero, R., Bussolati, B., Tetta, C., \& Camussi, G. (2010). Human liver stem cell-derived microvesicles accelerate hepatic regeneration in hepatectomized rats. Journal of Cellular and Molecular Medicine, 14, 1605-1618. https://doi.org/10.1111/j. 1582-4934.2009.00860.x.

39. Bruno, S., Grange, C., Deregibus, M. C., Calogero, R. A., Saviozzi, S., Collino, F., Morando, L., Busca, A., Falda, M., Bussolati, B., Tetta, C., \& Camussi, G. (2009). Mesenchymal stem cell-derived microvesicles protect against acute tubular injury. J. Am. Soc. Nephrol. JASN, 20, 1053-1067. https://doi.org/10.1681/ASN. 2008070798.

40. Radziszewska, A., Schroer, S. A., Choi, D., Tajmir, P., Radulovich, N., Ho, J. C., Wang, L., Liadis, N., Hakem, R., Tsao, M.-S., Penn, L. Z., Evan, G. I., \& Woo, M. (2009). Absence of Caspase-3 protects pancreatic $\beta$-cells from c-Myc-induced apoptosis without leading to tumor formation. The Journal of Biological Chemistry, 284, 10947-10956. https://doi.org/10.1074/jbc.M806960200.

41. Basinska, K., Marycz, K., Śmieszek, A., \& Nicpoń, J. (2015). The production and distribution of IL- 6 and TNF- $\alpha$ in subcutaneous adipose tissue and their correlation with serum concentrations in welsh ponies with equine metabolic syndrome. Journal of Veterinary Science, 16, 113-120. https://doi.org/10.4142/jvs. 2015.16.1.113.

42. Hosseinkhani, B., Kuypers, S., van den Akker, N. M. S., Molin, D. G. M., \& Michiels, L. (2018). Extracellular vesicles work as a functional inflammatory mediator between vascular endothelial cells and immune cells. Frontiers in Immunology, 9. https://doi. org/10.3389/fimmu.2018.01789.
43. Harrell, C. R., Jovicic, N., Djonov, V., Arsenijevic, N., \& Volarevic, V. (2019). Mesenchymal stem cell-derived Exosomes and other extracellular vesicles as new remedies in the therapy of inflammatory diseases. Cells, 8. https://doi.org/10.3390/ cells 8121605 .

44. Caramés, B., Taniguchi, N., Otsuki, S., Blanco, F. J., \& Lotz, M. (2010). Autophagy is a protective mechanism in normal cartilage, and its aging-related loss is linked with cell death and osteoarthritis. Arthritis and Rheumatism, 62, 791-801. https://doi.org/10.1002/ art.27305.

45. Green, D. R., \& Levine, B. (2014). To be or not to be? How selective autophagy and cell death govern cell fate. Cell, 157, 65-75. https://doi.org/10.1016/j.cell.2014.02.049.

46. Ariyasu, D., Yoshida, H., \& Hasegawa, Y. (2017). Endoplasmic reticulum (ER) stress and endocrine disorders. International Journal of Molecular Sciences, 18, 382. https://doi.org/10.3390/ ijms 18020382 .

47. Liao, Z., Luo, R., Li, G., Song, Y., Zhan, S., Zhao, K., Hua, W., Zhang, Y., Wu, X., \& Yang, C. (2019). Exosomes from mesenchymal stem cells modulate endoplasmic reticulum stress to protect against nucleus pulposus cell death and ameliorate intervertebral disc degeneration in vivo. Theranostics, 9, 4084 4100. https://doi. org/10.7150/thno.33638.

48. Chen, J., Chen, J., Cheng, Y., Fu, Y., Zhao, H., Tang, M., Zhao, H., Lin, N., Shi, X., Lei, Y., Wang, S., Huang, L., Wu, W., \& Tan, J. (2020). Mesenchymal stem cell-derived exosomes protect beta cells against hypoxia-induced apoptosis via miR-21 by alleviating ER stress and inhibiting p38 MAPK phosphorylation. Stem Cell Research \& Therapy, 11, 97. https://doi.org/10.1186/s13287-02001610-0.

Publisher's Note Springer Nature remains neutral with regard to jurisdictional claims in published maps and institutional affiliations. 